\title{
Holiness as friendship with Christ: Teresa of Avila
}

\begin{tabular}{|c|c|}
\hline \multicolumn{2}{|c|}{$\begin{array}{l}\text { Author: } \\
\text { Tara K. Soughers }{ }^{1,2} \text { (D) }\end{array}$} \\
\hline \multicolumn{2}{|c|}{$\begin{array}{l}\text { Affiliations: } \\
{ }^{1} \text { Centre for Practical } \\
\text { Theology, School of Theology, } \\
\text { Boston University, United } \\
\text { States of America }\end{array}$} \\
\hline $\begin{array}{l}{ }^{2} \text { Department } \\
\text { Testament Stu } \\
\text { Theology, Uni } \\
\text { Pretoria, Sout }\end{array}$ & $\begin{array}{l}\text { dies, Faculty of } \\
\text { versity of } \\
\text { Africa }\end{array}$ \\
\hline \multicolumn{2}{|c|}{$\begin{array}{l}\text { Project leader: A.G. van Aarde } \\
\text { Project number: } 2334682\end{array}$} \\
\hline \multicolumn{2}{|c|}{$\begin{array}{l}\text { Description: } \\
\text { Prof. Dr Tara Soughers (PhD } \\
\text { candidate and Doctor of } \\
\text { Theology Fellowship) is part } \\
\text { of the research project, } \\
\text { 'Biblical Theology and } \\
\text { Hermeneutics - Ad Hoc } \\
\text { project 'Holiness', directed by } \\
\text { Prof Dr. Andries van Aarde, } \\
\text { professor emeritus and } \\
\text { senior research fellow in the } \\
\text { Faculty of Theology of the } \\
\text { University of Pretoria, South } \\
\text { Africa. }\end{array}$} \\
\hline \multicolumn{2}{|c|}{$\begin{array}{l}\text { Corresponding author: } \\
\text { Tara K. Soughers, } \\
\text { tksoughers@comcast.net }\end{array}$} \\
\hline \multicolumn{2}{|c|}{$\begin{array}{l}\text { Dates: } \\
\text { Received: } 19 \text { Apr. } 2016 \\
\text { Accepted: } 12 \text { Aug. } 2016 \\
\text { Published: } 30 \text { Sept. } 2016\end{array}$} \\
\hline \multicolumn{2}{|c|}{$\begin{array}{l}\text { How to cite this article: } \\
\text { Soughers, T.K., 2016, } \\
\text { 'Holiness as friendship with } \\
\text { Christ: Teresa of Avila', HTS } \\
\text { Teologiese Studies/ } \\
\text { Theological Studies 72(4), } \\
\text { a3444. http://dx.doi. } \\
\text { org/10.4102/hts.v72i4.3444 }\end{array}$} \\
\hline \multicolumn{2}{|c|}{$\begin{array}{l}\text { Copyright: } \\
\text { (C) 2016. The Authors } \\
\text { Licensee: AOSIS. This } \\
\text { is licensed under the } \\
\text { Creative Commons } \\
\text { Attribution License. }\end{array}$} \\
\hline \multicolumn{2}{|l|}{ Read online: } \\
\hline 口ifing & $\begin{array}{l}\text { Scan this QR } \\
\text { code with your } \\
\text { smart phone or } \\
\text { mobile device } \\
\text { to read online. }\end{array}$ \\
\hline
\end{tabular}

Teresa of Avila, writing in the 16th century when ideas of holiness often excluded women and lay people, developed a radically inclusive understanding of holiness as friendship with Christ. Her idea also allowed for degrees of holiness, from those who completed only the necessary church requirements of confession and absolution all the way up to those who had a friendship that was modelled upon the relationship in the Song of Songs. It was a definition of holiness applicable to men and women, clergy, members of religious orders, and lay people. In addition, her understanding of holiness did not distinguish the holiness of ordinary lay people from that of the great saints of previous generations, for friendship with Christ was open to all.

\section{Introduction}

As with other ideas, the understanding of what constituted 'holiness' has not been static through Christian history. Indeed, Grace M. Jantzen believes that the understanding of mysticism, an idea often linked with holiness, has varied and that at least some of this variation led to gendered understandings (Jantzen 1995:326). Jantzen (1995) argues:

It was only with the development of the secular state, when religious experience was no longer perceived as a source of knowledge and power, that it became safe to allow women to be mystics. (n.p)

In fact, according to Jantzen, the equating of mysticism with an inexpressible experience correlates well with the silencing of women in the public realm in the early modern period in Europe (Jantzen 1995).

Often, ideas of holiness have been developed to exclude women or different criteria have been used for women and men. This was certainly the case in 16th-century Spain. Gillian T.W. Ahlgren notes that in that context, controls over the behaviour of women, especially for women who aspired to holiness, were pervasive and that the symbols chosen to promote conceptions of womanhood ... emphasised the primacy of humility and obedience' (Ahlgren 1996:23). This was in contrast to the active, virile understanding of holiness that H. Outram Evennett talks about as being prevalent in the 16th century for men (Evennett 1999:63). This difference can be explained, at least in part, by the heavy emphasis upon blood purity in 16th-century Spain, and the need for families to protect their honour by limiting the activity of women (Perry 1990:6). ${ }^{1}$ Any female impropriety negatively affected male family members, and so women needed to be carefully controlled and strictly confined to either cloister or home (Ruiz 2001:239).

In this time when holiness for women was defined very narrowly, frequently by strict seclusion and stringent ascetical practices, Teresa of Avila developed a much broader notion of holiness, an understanding that encompassed not only the saints and the religious but ordinary Christians as well, female and male, lay and clergy. This understanding of holiness was not based upon deeds or acts so much as upon relationship. For Teresa, holiness was defined as friendship with God.

\section{The Life and Times of Teresa of Avila²}

Teresa of Avila was born Teresa Sánchez de Cepeda y Ahumada on 25 March 1515, in Avila to Alonso Sánchez and his second wife, Beatriz de Ahumada. Her father, while still a youth, an uncle, and her grandfather were reconciled to the Inquisition in Toledo for the sin of secret Judaising, causing the family to flee to Avila where they could begin anew and where they were able to purchase a patent of nobility, something not technically possible for a family with impure bloodlines, that admitted them to the lower gentry. Teresa's mother's family were 'Old Christians', 1.'Limpieza de sangre, or genetic purity free from intermarriage with other religious groups, determined who could hold office or enjoy privilege, and it depended directly on female chastity'.

2.Quotes from Teresa of Avila's works are from the critical translations listed below. Prior to the page number in the footnote, chapter and subchapter (for instance, 1.2) are listed to facilitate comparisons with other translations or with Spanish versions of her works. 
and Teresa was raised in a devout Christian household. Teresa's mother died when Teresa was thirteen, prompting her to take the Virgin Mary for her mother. By her own account, Teresa was a popular and sociable young woman (Teresa of Avila 1987:2.2, 57). Concerns about her behaviour in regard to an older male cousin led her father to place her in the Augustinian Convent School of Our Lady of Grace when she was sixteen (Teresa of Avila 1987:2.6, 59).

Following a protracted and serious illness, Teresa joined the Carmelite convent of Encarnacion against her father's wishes. After many years there, she found herself being drawn into the practice of contemplative or 'mental' prayer. The conditions at Encarnacion, however, were not conducive to the practice of mental prayer. As a consequence, Teresa would found a total of 17 reformed or 'discalced' houses for women, as well as found the first discalced houses for men along with John of the Cross. When many spiritual works in Spanish were banned by the Valdes Index in 1549, Teresa would begin writing to provide resources for her nuns to learn what was necessary for living a reformed life, including the practice of mental prayer. Teresa died on 04 October 1582.

\section{Friendship in the Writings of Teresa of Avila}

Friendship is one of the most important images in the writings of Teresa of Avila. According to Soughers (2013):

Both amigo/amistad and compañero/compañia occur repeatedly throughout her writings, and she uses them in a variety of ways with respect to human beings, as well as with respect to God. (p. 120)

Teresa used the concept of friendship in three ways, namely, (1) to describe the incarnation, (2) to design her reformed houses around a small group of those dedicated to a life of prayer and (3) to name the progress of the spiritual life from ordinary Christian living all the way up to that of recognised saints. Friendship was an image that could express degrees of relationship as well as contain a wide variety of ways to express holiness. From more casual friendships to passionate betrothals, the way of friendship with Christ was a way open to all.

Although Teresa used friendship as an important image, it was not friendship as that relationship was normally practised in 16th-century Spain. For Teresa, companions and friends were not necessarily those of the same social class, but instead those who shared either the ideals of the movement to reform the Carmelite Order (often supporting it materially) or those whose friendship was one whose goal was to grow closer in relationship with God. The understanding of friendship expressed in her writings was actually closer to spiritual companionship than to simple friendship as it is normally envisioned. ${ }^{3}$ In fact, for Teresa, true friendship with another was defined by the goal of mutual growth in friendship with Christ. While Teresa rejoiced in her true friendships, any relationship that was focused upon things other than growing in relationship with Christ became a burden for her. After one of her visions, Teresa argued that:

I have never again been able to tie myself to any friendship or to find consolation in or bear particular love for any other persons than those I understand love Him and strive to serve Him; nor is it in my power to do so, nor does it matter whether they are friends or relatives. If I'm not aware that the persons seek to love and serve God or to speak about prayer, it is a painful cross for me to deal with them (Teresa de Jesus 2006:4.6, 55). ${ }^{4}$

Teresa was well aware that many relationships of friendship, even those in monasteries, did not always serve the purpose of helping one grow in relationship to God. In The Way of Perfection, she says:

For these great friendships are seldom directed toward helping one love God more. On the contrary, I think the devil gets them started so as to promote factions in religious orders. (Teresa of Avila 1980)

Teresa took pains to distinguish the type of friendship that would be helpful to the nuns in their own spiritual growth. To foster an atmosphere where all were true friends, Teresa limited the number of nuns in each of her reformed houses to thirteen so that cliques and subgroups would be more difficult to form. ${ }^{6}$ Teresa wanted and expected all of her nuns to be friends, carrying the responsibility for helping each other to grow in their friendship with Christ. This was a heavy burden but one that the nuns dared not refuse to accept out of any false modesty. There was no higher calling than this: to bring others into closer friendship with Christ. ${ }^{7}$

For Teresa, friendship with Christ was the true measure of holiness, both with respect to her own contemporaries as well as with respect to Christians in previous generations. In fact, for Teresa, it was their friendship with God that most distinguished the saints, and she held up several saints as exemplars of holiness for their friendships with God. Holiness was within reach of all people, for all could grow in their friendship with Christ.

While friendship was characteristic of the saints, this type of relationship was not restricted to a spiritual elite. Rather

4.Teresa of Avila, Life, 24.6, 211-212; 'Ello se ha cumplido bien, que nunca mas yo he podido asentar en amistad ni tener consolacion ni amor particular sino a personas que entiendo le tienen a Dios y le procuran server, ni ha sido en mi mano, ni me hace al caso ser deudos ni amigos. Si no entiendo esto, u es persona que trata de oracion, esme cruzpenosa tratar con nadie'.

5.Teresa of Avila, Way, 4.6; 55; 'Porque estas amistades grandes pocas veces van ordenadas a ayudarse a amar mas a Dios, antes creo las hace comenzar el demonio para comenzar bandos en las relisiones.' Teresa de Jesus, Camino de Perfeccion [Valladolid], in Obras Completas, 4.6, 254

6.'... but in this house where there are no more than thirteen - nor must there be any more - all must be friends, all must be loved, all must be held dear, all must be helped.' Teresa of Avila, Way, 4.7, 55; '... que en esta casa, que no son mas de trece, ni lo han der ser. Aquí todas han de ser amigas, todas se han de amar, todas se han de querer, todas se han de ayudar ...' Teresa de Jesus, Camino [Valladolid], 4.7, 254.

7.I I should very much like to advise these souls to be careful not to hide the talent since it seems God desires to choose them to bring profit to many others, especially in these times when staunch friends of God are necessary to sustain the weak.' Teresa of Avila, Life, 15.5, 141; 'Querrialas mucho avisar que miren no ascondan el talento, pues que parece las quiere Dios escoger para provecho de otras muchas, en talento, pues que parece las quiere Dios escoger para provecho de otras muchas, en
especial en estos tiempos que son menester amigos fuertes de Dios para sustentar especial en estos tiempos que son menester amigos fuertes de Dios para sustenta
los flacos ...' Teresa de Jesus, Vida, 15.5, 89 . 
than reserving friendship with God for those great friends of God mentioned in her Life or even great contemplatives among the vowed religious, Teresa argued that this friendship, this holiness, is possible for all Christians through friendship with Christ, and it is not just the property of the 'saints'.

\section{Friendship with God as holiness}

In defining what constitutes a true friendship, Teresa always referred back to the truest example, and for Teresa, that example was Christ. In her Life, Teresa says, 'The Lord helps us, strengthens us, and never fails; $\mathrm{He}$ is a true friend'. In fact, for Teresa the incarnation was proof of Christ's friendship with the human race. In her Meditations on the Song of Songs, Teresa likens the kiss of the bride and the groom to the kiss of friendship. 'I also wondered whether she was asking for that union so great that God became man, for that friendship that He effected with the human race' ${ }^{9}$

In fact, the relationship with the incarnated Christ was so central to the spiritual life that Teresa dared to disagree with the leading authorities of her day. While the prevailing wisdom was that all images eventually dropped away from the life of prayer until one reached the heights of spiritual progress in apophasis, Teresa believed that it was essential to retain the image of Christ as a central element in the life of prayer no matter what level of spiritual maturity one had achieved. She had tried, in her own life, to follow the spiritual advice of the learned men, and found that her spiritual progress remained stagnant until she returned to using images of Christ in prayer. She says:

But if I should have kept to that practice, I believe I would never have arrived at where I am now because in my opinion the practice is a mistaken one..$^{10}$ (Teresa of Avila, Life, 22.2, 192)

Teresa believed that through the incarnation, Christians were provided with a spiritual companion who could accompany one on the spiritual journey. Without that help, Christians were apt to lose their way, as she had. To refuse to accept the importance of the image of Christ was a sign, for Teresa, of a lack of humility. As humility was necessary for progress in the spiritual life, such an attitude was an impediment to further progress. ${ }^{11}$ Secondly, Teresa emphasised that we are embodied creatures, saying, 'we are not angels but we have a body'. ${ }^{12}$ She believed that banishing all images, including the image of Christ, was to try to pretend that we were something we were not. Such pretending was an act of foolishness. As we are embodied creatures, subject to all of the difficulties

\footnotetext{
8.Teresa of Avila, Life, 22.6, 194; "es ayuda y da esfuerzo; nunca falta; es amigo verdadero.' Teresa de Jesus, Vida, 22.6, 122.

9.Teresa of Avila, Meditations on the Song of Songs, in The Collected Works of St. Teresa of Avila, vol. 2, 1.10, 221; 'Tambien he pensado si pedia aquel ayuntamiento tan grande, como fue hacerse Dios hombre, aquella amistad que hizo con el genero humano.' Teresa de Jesus, Meditaciones sobre los Cantares, in Obras Completas, 1.11, 427.

10.'y si me huviera estado en ello, creo nunca huviera llegado a lo que ahora, porque, a mi parecer, es engaño.' Teresa de Jesus, Vida, 22.2, 120-121.

11.Teresa of Avila, Life, 22.5, 193.

12.Ibid., 22.10, 195; 'nosotros no somos ángeles, sino tenemos cuerpo.' Teresa de Jesus, Vida, 22.10, 123.
}

that such a state entails, the image of Christ can and should be a comfort and a companion to us:

When one is in the midst of business matters, and in times of persecutions and trials, when one can't maintain so much quietude, and in times of dryness, Christ is a very good friend because we behold Him as man and see Him with weaknesses and trials - and He is company for us. ${ }^{13}$ (Teresa of Avila, Life, 22.10, 196)

Although no Christian could serve as a friend as effectively as Christ, Teresa still believed that it was important to have that human companionship. When Teresa could not always find it in contemporaries, saints could serve this role as well. Indeed, these friends often seemed more alive to Teresa than her earthly companions. Speaking of heaven, she says:

It happens to me sometimes that those who I know live there are my companions and the ones in whom I find comfort; it seems to me that they are the ones who are truly alive and that those who live here on earth are so dead that not even the whole world, I think, affords me company, especially when I experience those impulses. ${ }^{14}$ (Teresa of Avila, Life, 38.6, 332)

For Teresa, the saints were not only friends and companions, but they also served as models of what friendship with Christ was all about. For them, friendship with God was of the utmost importance, and it was their model of friendship with God that Teresa cited as an example of the type of life she was advocating in her monasteries:

Let us consider the glorious St. Paul: it doesn't seem that any other name fell from his lips than that of Jesus, as coming from one who kept the Lord close to his heart. Once I had come to understand this truth, I carefully considered the lives of some of the saints, the great contemplatives, and found that they hadn't taken any other path: St. Francis demonstrates this through the stigmata; St. Anthony of Padua, with the Infant; St. Bernard found his delight in the humanity; St. Catherine of Siena - and many others about whom your Reverence knows more than I. ${ }^{15}$ (Teresa of Avila, Life, 22.7, 194)

For Teresa the saints were distinguished by a shared characteristic - their friendship with Christ - and this friendship was able to encompass all of the different ways in which their holiness had been manifested. Friendship with Christ was demonstrated by Paul's reliance upon the name of Christ and Francis of Assisi's stigmata, by Anthony's devotion to the infant Christ, and by saints as diverse as Benedict of Nursia and Catherine of Siena. According to Teresa, this list does not encompass all of the ways in which the friendship of

13.'Esto no es tan ordinario, que en negocios y persecuciones y travajos, cu.............. puede tener tanta quietud, y en tiempo de sequedades, es muy buen amigo Cristo, porque le miramos Hombre y vémosle con flaquezas y travajos, y es compañia.' Teresa de Jesus, Vida, 22.10, 123

14.'Tambien me parece me aprovecho mucho para conocer neustra verdadera tierra y ver que somos aca peregrinos, y es gran cosa ver lo que hay alla y saber adonde hemos de vivir.Porque si uno ha de ir a vivir de asiento a una tierra, esle gran ayuda, para pasar el travajo del camino, haver visto que es tierra adonde ha de estar muy a su descanso, y tambien para considerar las cosas celestiales y procurar que nuestra conversacion sea alla, hacese con facilidad.' Teresa de Jesus, Vida, 38.6, 208.

15.'Miremos a el glorioso san Pablo, que no parece se le caia de la boca siempre Jesus, como quien le tenía bien en el corazon. Yo he mirado con cuidado, despues que esto he entendido de algunos santos, grandes contemplativos, y no ivan por otro camino: san Franciso de muestra de ello en las llagas; sant Antonio de Padua, el Nino; san Bernardo se deleitava en la Humanidad; santa Catalina de Sena, otros Nino; san Bernardo se deleitava en la Humanidad; santa Catalina de Sena, otros
muchos, que vuesa merced sabra mijor que yo.' Teresa de Jesus, Vida, 22.7, 122. 
the saints has been manifested: there are many more. All of these saints were, in their own ways, great friends of Christ, and great models of that friendship for her nuns.

\section{Degrees of friendship and degrees of holiness}

While all of the saints that Teresa recognised as exemplars of friendship with Christ were saints of great holiness, Teresa recognised that friendship with Christ, and hence holiness, was a matter of degree. Just as humans could have casual friends as well as very close friends, friends of Christ were also found in a variety of levels, from reasonably observant lay Christians to people of great sanctity. Teresa's most extensive description of the possible levels of friendship is found in her Meditations on the Song of Songs. While Teresa described the easier forms of friendship, in part, to warn her nuns not to settle for too little, all of these relationships were labelled as friendship with Christ, and hence were holy.

\section{According to Teresa:}

There are some persons who have already attained friendship with the Lord because they have confessed their sins well and have repented, but 2 days don't pass before they return to them. ${ }^{16}$ (Teresa of Avila, Meditations, 2.17, 230)

For Teresa, this seems to be the minimum requirement for friendship with Christ. A willingness to confess and to repent, even if the person is not able to maintain that state of grace for any length of time, is sufficient to establish a relationship of friendship. If, however, Teresa acknowledges that this is indeed true friendship, she does not want her nuns to settle for this type of friendship. She warns her nuns that there should be some change in their lives as a result of their friendship with Christ, because it is harder to remove sins that have taken root, and they should not have to confess the same faults to their confessors every time. ${ }^{17}$

The next level of friendship that Teresa describes is a considerable advance over the most basic level of friendship with Christ. These friends are those who guard themselves against mortal sins. Of these, Teresa says:

These persons even though they guard themselves against sinning mortally do not fail to fall now and again, from what I believe. For they care little about venial sins; they commit many daily, and thus they are very close to committing mortal sins ${ }^{\prime}{ }^{18}$ (Ibid. 2.20, 231)

In their casual lack of concern about their own sinfulness, their lazy reliance on holy water and the remedies of the church, and their unwillingness to give up their enjoyments,

16.'Creed que va mucho en esto, pues hay unas personas que han ya alcanzado lo amistad de Señor, porque confesaron bien sus pecados y se arrepintieron, mas no pasan dos días que se tornan a ellos.' Teresa de Jesus, Meditaciones [Alba], 2.18, 437.

17.Teresa of Avila, Meditations, 2.17-2.18, 230 .

18.Ibid., 2.20, 231; 'de personas que se guardan de ofender al Señor mortalmente. Harto han alcanzado los que han llegado aquí, sigún está el mundo. Estas personas, aunque se guardan de pecar mortalmente, no dejan de caer de cuando, a lo que creo; porque no se les da nada de pecados veniales, aunque hagan muchos al día, y ansí están bien cerca de los mortales.' Teresa de Jesus, Meditaciones [Alba], 2.22, 438-439. they grieve Teresa. Teresa cautions her nuns not to use the good things that Christ has given for the forgiveness of sins as an excuse to take even venial sins lightly. ${ }^{19}$

On the next step in the path of friendship are those who take both mortal and venial sins seriously - trying to avoid offending God in anything - but who are still enjoying the things of the world. Teresa says, "They have their times for prayer. Our Lord gives them tenderness and tears. Yet, they do not want to give up the enjoyments of this life' ${ }^{20}$ While Teresa admits that it is sufficient if they maintain the practice of virtue, she considers this a dangerous path. She warns her nuns that this style of life is likely to ensure that the person will grow lax in their practices, leaving them vulnerable to temptation. ${ }^{21}$ Living in one's own house, instead of in a religious community, makes it more difficult to maintain a proper perspective on one's own virtue. The lack of mortification can make it very difficult to live a holy life, but not impossible. ${ }^{22}$

Even nuns who have given up all material possessions, however, have not necessarily attained the type of friendship that the bride should seek. For the desire to protect one's honour can survive even in the midst of monastic life. As Teresa herself knew, the desire to be seen as acceptable in the eyes of others is a powerful motivator. These friends of Christ:

would not want to do anything that was not really acceptable to men as well as to the Lord; great discretion and prudence. It is not always easy to reconcile these two, for the trouble is that without one's being aware the interests of the world almost always gain more than do those of God. ${ }^{23}$ (Teresa of Avila, Meditations, 2.26, 234)

At the next step on the ladder of friendship are those who have put aside concerns for their personal honour. Because they do not really embrace the cross, it is a heavy burden to them. Even if they do believe that they have given up their concern with their personal honour, however, the concern for it can arise at any time. If they have not been sufficiently mortified, they are likely to be fearful of what others might say of them, and they are not capable of embracing danger for Christ's sake. ${ }^{24}$

For Teresa, the highest friendship is that type of friendship described in the Song of Songs, and it is the type of friendship that she exhorts her nuns to aspire to achieve. This is how Teresa describes that type of friendship:

19.Teresa of Avila, Meditations, 2.20, 231.

20.Ibid., 2.22, 232; 'Tienen sus ratos de oración, dales nuestro Señor ternuras y lágrimas; mas no querrían ellas dejar los contentos de esta vida.' Teresa de Jesus, Meditaciones [Alba], 2.24, 440 .

21.Teresa of Avila, Meditations, 2.20, 231

22.Ibid., 2.25, 234 .

23.Ibid., 2.26, 234; 'no querrían hacer cosa que no fuese bien acepta a los hombres, como al Señor; gran discreción y prudencia. Puédense harto mal concertar siempre estas dos cosas; y es el mal que casi, sin que ellos entiendan su imperfeción, siempre gana más el partido del mundo que el de Dios.' Teresa de Jesus, Meditaciones [Alba], 2.30, 442 .

24.Teresa of Avila, Meditations, 2.28-2.29, 235. 
Thus, when the bride knows she is serving the Bridegroom in something, there is so much love and desire to please Him that she doesn't listen to the reasons the intellect will give her or to the fears it will propose. But she lets faith so work that she doesn't look for her own profit or rest; rather, she succeeds now in understanding that in this service lies all her profit. ${ }^{25}$ (Teresa of Avila, Meditations, 3.1, 236-237)

There are five signs that the Lord gives that someone has reached this stage of friendship. The first is that they demonstrate 'contempt for all earthly things', recognising how little they matter once one has this friendship with Christ. The second is not desiring one's own good, for all that matters is the good of the bridegroom, and it is vanity to focus upon one's own good. The third is rejoicing only with those who love the Lord. The fourth is that life becomes wearisome. The last sign is a fear that 'God may not make use of it [the soul] by giving it trials and the occasions for serving Him even at a great cost to itself' ${ }^{26}$ This, for Teresa, is that friendship so well described in the Song of Songs and the pinnacle of earthly holiness. While it is more difficult for those in the world than those in the monastic life, it is open to all.

\section{Conclusion}

In her book, The Interior Castle, Teresa makes it clear that she believes that lay people are called to holiness in the same way that the religious are called, to all seven levels of her interior castle, and that there is no reason to believe that they cannot also reach the highest levels of friendship with Christ.

I believe that through the goodness of God there are many of these souls in the world .... And, in my opinion, there is no reason why entrance even into the final dwelling place should be denied these souls, nor will the Lord deny them this entrance if they desire it; for such a desire is an excellent way to prepare oneself so that every favor may be granted. ${ }^{27}$ (Teresa of Avila, The Interior Castle, in The Collected Works of St. Teresa of Avila, vol. 2, III: $1.5,306)$

Although Teresa acknowledged that the monastic life, with its emphasis upon mortification and humility, was an easier, and indeed perhaps even a safer, route for the spiritual journey than life in the world, it was not a sure one. Likewise, life in the world, with all of the cares and responsibilities that

\footnotetext{
25.'en entendiendo que sirve más a su Esposo en una cosa, haya tanto amor y deseo de contentarle, que no escuche las razones que le dará el entendimiento ni los temores que le porná, sino que deje obrar la fe de manera que no mire provecho ni descanso, sino acabe ya de entender que en esto está todo su provecho.' Teresa de Jesus, Meditaciones [Alba], 3.1, 445.

26.'Llegada aquí el alma, no tiene que temer, si no es si no ha de merecer que Dios se quiera servir de ella en darla travajos y ocasión para que pueda servirle, aunque sea muy a su costa.' Teresa de Jesus, Meditaciones [Alba], 3.3, 445.

27.'De éstas, por la bondad del Señor, creo hay muchas en el mundo ... Cierto, estado para desear y que al parecer no hay por qué se les niegue la entrada hasta la postrera morada, ni se la negará el Señor si ellos quieren, que linda dispusición es para que las haga toda merced.' Teresa de Jesus, Moradas del Castillo Interior, in Obras Completas, III:1.5, 488 .
}

come with those states of life, does not preclude significant spiritual growth. Nuns do not always progress into brides of Christ, and lay people may indeed progress despite all impediments to true union.

While all Christians are called to grow in their holiness, in their friendship with Christ, Teresa notes that Christ is a very patient friend, counting even those who confess their faults and relapse 2 days later as friends. Even though Christians are called to grow in their friendship with Christ, Christ is patient, meeting each person where they are. The ways of friendship with Christ are many and varied, and holiness of life is within the grasp of all Christians.

Teresa's idea of holiness as friendship with Christ made holiness something that was not only the property of the ordained and the religious. Her refusal to place the religious in a holier state simply because of their vows or exclude the laity from certain levels of holiness because of their need to attend to the business appropriate to their states of life is noteworthy in the context of 16th-century Spain. Not only did she challenge the differences between the laity and the religious, but her definition of holiness would challenge distinctions between male and female as well. In contrast to norms of her time, Teresa's definition of holiness was equally applicable to men and women. This very egalitarian notion of holiness may make Teresa's conception of holiness as friendship with Christ particularly useful for contemporary Christians.

\section{Competing interests}

The author declares that she has no financial or personal relationships which may have inappropriately influenced her in writing this article.

\section{References}

Ahlgren, G.T., 1996, Teresa of Avila and the politics of sanctity, Cornell University Press, Ithaca, NY.

De Dios, E.M. \& Steggink, O. (ed.), 2006, Santa Teresa de Jesus, Obras Completas, Biblioteca de Autores Cristianos, Madrid.

Evennett, H.O., 1999, 'Counter-reformation spirituality', in D.M. Luebke (ed.), The counter-reformation: The essential readings, 1st edn., pp. 48-63, Blackwell Publishers, London.

Jantzen, G.M., 1995, Power, gender and Christian Mysticism, Cambridge University Press, Cambridge, UK.

Perry, M.E., 1990, Gender and disorder in early modern Seville, Princeton University Press, Princeton, NJ.

Ruiz, T.F., 2001, Spanish Society, 1400-1600, Pearson Education, Harlow.

Soughers, T.K., 2013, 'Friendship with Saints: A practical theological reading of Teresa of Avila as a spiritual companion', PhD dissertation, Boston University.

Teresa de Jesus, 2006, 'Libro de la Vida', in E.M. de Dios \& O. Steggink (ed.), Santa Teresa de Jesus, Obras Completas, Biblioteca de Autores Cristianos, Madrid, pp. 24.6, 133.

Teresa of Avila, 1987, The collected works of St. Teresa of Avila, vol. 1, 2nd edn., transl. K. Kavanaugh \& O. Rodriguez, ICS Publications, Washington, DC.

Teresa of Avila, 1980, The collected works of St. Teresa of Avila, vol. 2., transl. K. Kavanaugh \& O. Rodriguez, ICS Publications, Washington, DC. 